\title{
sciendo
}

\author{
Current Issues in Pharmacy and Medical Sciences \\ Formerly ANNALES UNIVERSITATIS MARIAE CURIE-SKIODOWSKA, SECTIO DDD, PHARMACIA
}

journal homepage: http://www.curipms.umlub.pl/

\section{Neurological manifestation of cancer - paraneoplastic syndromes}

\author{
Katarzyna Szklener ${ }^{\star}$ (i), Slawomir Mandziuk ${ }^{\circledR 0}$
}

Department of Clinical Oncology and Chemotherapy, Medical University of Lublin, Poland

\begin{tabular}{|c|c|}
\hline ARTICLE INFO & ABSTRACT \\
\hline $\begin{array}{l}\text { Received } 01 \text { February } 2021 \\
\text { Accepted } 20 \text { May } 2021\end{array}$ & $\begin{array}{l}\text { Neurological paraneoplastic syndromes (NPS) belong to a heterogeneous group } \\
\text { of disorders affecting the nervous system. NPS occur as a result of immunological reaction }\end{array}$ \\
\hline $\begin{array}{l}\text { Keywords: } \\
\text { neurological paraneoplastic } \\
\text { syndromes, } \\
\text { cancer, } \\
\text { antineural antibodies. }\end{array}$ & $\begin{array}{l}\text { to the tumor. As a result, the isolated syndrome is formed and manifests itself in many } \\
\text { different ways, for example: limbic encephalitis, ataxia, dominant cerebellar degeneration, } \\
\text { psychiatric disturbances, myasthenia gravis or diffuse encephalomyelitis. Detection of } \\
\text { NPS is solely based on the presence of specific anti-neural antibodies. Although NPS had } \\
\text { been previously considered unresponsive to therapy, some research has shown that there } \\
\text { are effective therapies, including cancer- and immunotherapy targeted therapies. }\end{array}$ \\
\hline
\end{tabular}

\section{INTRODUCTION}

NPS are rare complications associated with cancer, with the epidemiology still remaining to be defined. Latest largescale population-based studies from Europe approximate the incidence of NPS to below 1/100.000 persons-years [1,2]. Early diagnose of NPS is important as it allows for early intervention and thus increases the chances of treatment to be effective [3-4]. In most cases, treatment of NPS, based on conventional methods, is generally ineffective at the time of treating 5 , yet even so, some NPS can be fully cured $[3,4,6]$.

NPS is present in diverse clinical manifestations. The most commonly reported NPS are limbic encephalitis, cerebellar degeneration and encephalomyelitis [1,7]. The most common cancers associated with NPS are breast cancer, ovarian cancer, small cell lung cancer, thymoma, neuroendocrine tumors, lymphoma $[3,4]$ and stomach cancer [5]. NPS development usually precedes the growth of cancer tumor, which results in misdiagnosis $[1,2,8]$.

One major study suggests that PNS can be induced by cancer treatment, as it results in systemic autoimmunity. However, exact data is still limited because of complexities in diagnosis and the lack of relevant studies [9].

Recent findings point to the activity of anti-neuronal antibodies. These have been well described [5], and for some, new data is available [10]. However, abnormalities and the rarity of these disorders result in diagnostic delays. Early intervention may lead to better results and therefore a review of more frequent antibody related NPS is justified. Greater focus on NPS that are commonly seen as autoimmune

\footnotetext{
* Corresponding author

e-mail: katarzyna.szklener@umlub.pl
}

encephalitis where antineural antibodies attack synaptic or surface proteins, will provide an increasing number of new observations [11]. Specific management strategies in NPS treatment vary extensively depending on the etiology underlying the symptoms [12].

\section{The pathophysiology of paraneoplastic syndromes}

Paraneoplastic neurological syndromes result from disrupted biochemical pathways and involve molecular mimicry due to tumors displaying proteins that resemble sequences found in the nervous system cells [13]. Immunological responses result in antibodies targeting both tumor and neurons and often manifest themselves as the antineural antibodies that are present in serum and cerebro-spinal fluid (CSF) [14-16].

The formation of NPS differs depending on the affected tissue. They are, however, a result of autoimmune response to the formation of tumor. Development of diagnostic tests, that are now widely available, became possible thanks to the characterisation of NPS-related antineural antibodies.

Blood tests of cancer patients without NPS usually give negative result for antibodies at low titers. Moreover, the test method for some antibodies and whether serum or CSF has been used increases the risk of false results. In addition, antibody titres are higher in CSF than in the serum in cases of NPS affecting the central nervous system (CNS) and dorsal root ganglia. Therefore, testing the serum may be misleading and clinical criteria should be used for the diagnosis of NPS - with the antibody test applied as confirmation.

NPS-related antineural antibodies can be divided into two groups. One is of antibodies that almost always indicate that 
the disorder is paraneoplastic when detected. The antibodies in this group bind to intracellular neuronal antigens, which also serve as markers for cancer detection. These antibodies, called 'onconeural antibodies', are not directly pathogenic, rather, they are cytotoxic $\mathrm{T}$ cells that mediate in neuronal dysfunction and often cause irreversible damage and the death of neurons. For this reason, the response to treatment is rather poor [17].

Another group of antibodies have a strong affinity for neuronal or synapsis surface receptors. Their direct interaction with target antigens results in the mediation of neuronal dysfunction. Interaction of such antibodies with proteins in the CNS leads to the autoimmune associated syndromes, also known as 'autoimmune encephalitis'. The common clinical feature is that the same syndrome and antibody are present in patients with or without cancer. In addition, patients often recover fully or gain a marked improvement through therapy to remove antibodies and tumor, if present; neurological relapses occur with varying frequency depending on the syndrome [18].

In paraneoplastic cerebellar degeneration (PCD), which is associated with malignancy, antibodies bind to proteins expressed by Purkije cells, causing their degradation. The most prevalent symptoms of PCD are dysarthria, nystagmus and trunk, as well as limb ataxia, which becomes symmetric in every patient. Brain stem related symptoms such as dysphagia and nystagmus have also been reported [19]. PCD develops into pancreaticbrain dysfunction usually within weeks, but sometimes it can happen faster. At first, inflammatory process can be detected from analysis of CSF. Levels of white blood cell count, protein count and dooponic gamma immunoglobulin ( $\mathrm{IgG})$ synthesis are increased, but neuroimaging is usually normal. Late neuroimaging studies reveal signs of extensive cerebellar atrophy after months or years $[19,20]$.

In $60 \%$ of all cases, PCD can be associated with onconeural antibodies, with the exception of calcium channel gated antibodies (VGCC), which only rarely target neuronal cell surfaces. Specific antibodies, the type of cancer and neurological syndrome are all strongly linked together. Isolated cerebellar syndrome usually occurs in patients with Hodgkin's lymphoma and Tr/DNER antibodies or Yo antibodies in case of ovarian or breast cancer. Patients with PCD, small-cell lung cancer (SCLC) and $\mathrm{Hu}$ antibodies often have additional symptoms of a more diffuse encephalomyelitis [20-22].

Limbic encephalitis is characterised by subacute beginning of memory impairment. Further additional symptoms come with time. These include behavioural changes, anxiety, depression, and seizures. Limbic encephalitis belongs to a spectrum of paraneoplastic syndromes, being most commonly associated with lung cancer [23]. As in other kinds of NPL manifestation, it seems crucial to look for coexisting antibodies. Most frequently detected antibodies in that pathologic condition are the anti-Hu and Ma2 antibodies, whereas most frequently detected cancers are SCLC or germ cells tumor (GCT). We are able to detect tumour in only 60 percent of all cases [24].

A neurologic disorder that manifests with behavioural changes is anti-N-methyl-D-aspartate receptor encephalitis (NMDAR). Clinical symptoms of NMDAR additionally include memory impairment, speech disorders, seizures and disturbance of consciousness. Literature connects NMDAR mainly with teratoma among young women. However, there are reports of NMDAR induced by treatment with checked point inhibitors of some other cancers $[25,26]$.
Table 1. Summary of NPSs discussed

\begin{tabular}{|c|c|c|c|c|}
\hline Syndrome & Related cancer & Related antibodies & $\begin{array}{l}\text { Signs and } \\
\text { symptoms }\end{array}$ & Complications \\
\hline $\begin{array}{l}\text { Limbic } \\
\text { encephalitis }\end{array}$ & $\begin{array}{c}\text { Lung cancer } \\
\text { (SCLC), GCT } \\
\text { and others } \\
{[23,24]}\end{array}$ & $\begin{array}{c}\text { Anti-Hu, } \\
\text { Ma2; }\end{array}$ & $\begin{array}{c}\text { memory } \\
\text { impairment, } \\
\text { behavioural } \\
\text { changes, anxiety, } \\
\text { depression, } \\
\text { seizures; }\end{array}$ & \\
\hline $\begin{array}{l}\text { PCD } \\
\text { or } \\
\text { encephalomyelitis }\end{array}$ & $\begin{array}{l}\text { Various } \\
\text { malignacies; } \\
\text { Hodgkins } \\
\text { lymphoma; } \\
\text { ovarian cencer, } \\
\text { breast cancer } \\
\text { and others; } \\
\text { SCLC [19-22] }\end{array}$ & $\begin{array}{c}\text { Various } \\
\text { onconeuronal, } \\
\text { excluding VGCC } \\
\text { Tr/DNER; } \\
\text { Yo; } \\
\text { Anti-Hu [19-22] }\end{array}$ & $\begin{array}{c}\text { dysarthria, } \\
\text { nystagmus and } \\
\text { trunk, as well } \\
\text { as limb ataxia, } \\
\text { dysphagia, } \\
\text { nystagmus [19] }\end{array}$ & $\begin{array}{l}\text { Purkije cells } \\
\text { degradation, } \\
\text { pancreatic-brain } \\
\text { dysfunction, } \\
\text { extensive } \\
\text { cerebellar } \\
\text { atrophy }[19,20]\end{array}$ \\
\hline NMDAR & $\begin{array}{l}\text { anti-N-methyl-D- } \\
\text { aspartate }[25,26]\end{array}$ & \begin{tabular}{|c|} 
teratoma \\
(in young women) \\
and possibly \\
others $[25,26]$
\end{tabular} & \begin{tabular}{|c|} 
behavioural \\
changes, memory \\
impairment, \\
speech disorders, \\
seizures and \\
disturbance of \\
consciousness \\
{$[25,26]$}
\end{tabular} & \\
\hline
\end{tabular}

\section{DISCUSSION}

Because NPS disorders are rare incidences, only a few physicians have seen or treated them. Therefore, patients with NPS should consult a specialist experienced in the diagnosis and treatment of such neurological disorders.

Detailed prognoses for people with paraneoplastic syndromes are related to each individual case. Therefore, the prognosis for paraneoplastic syndromes may vary considerably. Prophylactic measures include routine medical checkups (especially neurological and oncological), notably when the patient recognizes subtle changes in his or her own body. Treatment involves therapies to reduce or slow down neurological degeneration, as well as therapies to eliminate the underlying cancer, such as chemotherapy, radiotherapy and surgery. In this scenario, rapid diagnosis and treatment are crucial for the patient's best chance of recovery.

\section{SUMMARY}

Because NPS disorders are rare incidences, only a few physicians have seen or treated them. Therefore, patients with NPS should consult a specialist experienced in the diagnosis and treatment of such neurological disorders.

Detailed prognoses for people with paraneoplastic syndromes are related to each individual case. Therefore, the prognosis for paraneoplastic syndromes may vary considerably. Prophylactic measures include routine medical check-ups (especially neurological and oncological), notably when the patient recognizes subtle changes in his or her own body. Treatment involves therapies to reduce or slow down 
neurological degeneration, as well as therapies to eliminate the underlying cancer, such as chemotherapy, radiotherapy and surgery. In this scenario, rapid diagnosis and treatment are crucial for the patient's best chance of recovery.

\section{ORCID iDs}

Katarzyna Szklener (1) https://orcid.org/0000-0001-8033-3574 Sławomir Mańdziuk (D)https://orcid.org/0000-0002-9812-0777

\section{REFERNCES}

1. Vogrig A, Gigli GL, Segatti S, Corazza E, Marini A, Bernardini A, et al. Epidemiology of paraneoplastic neurological syndromes: a population-based study. J Neurol. 2020;267(1):26-35.

2. Hébert J, Riche B, Vogrig, A, Muñiz-Castrillo S, Joubert B, Picard $G$, et al. Epidemiology of paraneoplastic neurologic syndromes and autoimmune encephalitides in France. Neurol Neuroimmunol Neuroinflam. 2020;7:E883.

3. Ejma M. Paraneoplastic neurological syndromes. Family Med Primary Care Rev. 2012;14: 447-52.

4. Graus F, Dalmau J. Paraneoplastic neurological syndromes. Curr Opin Neurol. 2012;25:795-801.

5. Molina-Garrido MJ, Guillén-Ponce C, Martínez S, Guirado-Risueño M. Diagnosis and current treatment of neurological paraneoplastic syndromes. Clin Transl Oncol. 2006;8(11):796-801.

6. Liapi A, Herrera Gómez R, Sakeliades E, Sariwalaza I. EP974 Review of three cases of high grade serous ovarian cancer associated with cerebellar atrophy and acute inflammatory demyelinating polyneuropathy. IJGC. 2019;29:A516-A517.

7. Altabakhi IW, Babiker HM. Paraneoplastic Limbic Encephalitis. In: StatPearls [Internet]. Treasure Island (FL): StatPearls Publishing; 2020. Available from: https://www.ncbi.nlm.nih.gov/books/ NBK519523/

8. Vogrig A, Gigli GL, Segatti S, Corazza E, Marini A, Bernardini A, et al. Epidemiology of paraneoplastic neurological syndromes: a population-based study. J Neurol. 2020;267(1):26-35.

9. Honnorat J, Viaccoz A. New concepts in paraneoplastic neurological syndromes. Rev Neurol. 2011;167:729-36.

10. Gozzard P, Maddison P. Which antibody and which cancer in which paraneoplastic syndromes? Pract Neurol. 2010;10:260-270.

11. Williams JP, Carlson NG, Greenlee JE. Antibodies in autoimmune human neurological disease: Pathogenesis and immunopathology. Semin Neurol. 2018;38(3):267-77.
12. Devine MF, Kothapalli N, Elkhooly M, Dubey D. Paraneoplastic neurological syndromes: clinical presentations and management. Ther Adv Neurol Disord. 2020;14:1-19.

13. Liblau R, Benyahia B, Delattre JY. The pathophysiology of paraneoplastic neurological syndromes. Ann Med Interne. 1998;149(8):512-520.

14. Miao S, Liao S, Li H, Niu B, Hu H, Qian Y, et al. Retrospective study of paraneoplastic neurological syndromes in a Chinese Han population from Shandong, East China. Int J Neurosci. 2018;128(9):821-7.

15. van Coevorden-Hameete MH, van Beuningen SFB, Perrenoud M, Will L, Hulsenboom E, Demonet J, et al. Antibodies to TRIM46 are associated with paraneoplastic neurological syndromes. Ann Clin Transl Neurol. 2017;4(9):680-6.

16. Kwiatkowski S, Kolasińska K, Knap B, Przystupski D, Kotowski $\mathrm{K}$, Bartosik W, et al. An overview of paraneoplastic neurological syndromes-pathophysiology and clinical insight. WSN. 2018,108:87-98.

17. Honnorat J. Onconeural antibodies are essential to diagnose paraneoplastic neurological syndromes. Acta Neurol Scand Suppl. 2006;183:64-8.

18. Alexopoulos H, Dalakas MC. The immunobiology of autoimmune encephalitides. J Autoimmun. 2019;104:102339.

19. Vernino S. Paraneoplastic cerebellar degeneration. Handb Clin Neurol. 2012;103:215-23.

20. Madhavan AA, Carr CM, Morris PP, Flanagan EP, Kotsenas AL, Hunt $\mathrm{CH}$, et al. Imaging review of Paraneoplastic Neurologic Syndromes. AJNR. 2020;41(12):2176-87.

21. Sakai K. Paraneoplastic cerebellar degeneration. Brain Nerve. 2010;62(4):357-64.

22. Newman MP, Blum S, Wong R, Scott J, Prain K, Wilson R, et al. Autoimmune encephalitis. Intern Med J. 2016;46(2):148-57.

23. Shen K, Xu Y, Guan H, Zhong W, Chen M, Zhao J, Li L, Wang M. Paraneoplastic limbic encephalitis associated with lung cancer. Sci Rep. 2018;8(1):6792.

24. Budhram A, Leung A, Nicolle MW, Burneo JG. Diagnosing autoimmune limbic encephalitis. CMAJ. 2019;13;191(19):E529-E534.

25. Liu CY, Zhu J, Zheng XY, Ma C, Wang X. Anti-N-methyl-D-aspartate receptor encephalitis: A severe, potentially reversible autoimmune encephalitis. Mediators Inflamm. 2017;2017:6361479.

26. Williams TJ, Benavides DR, Patrice KA, Dalmau JO, de Ávila AL, Le DT, et al. Association of autoimmune encephalitis with combined immune checkpoint inhibitor treatment for metastatic cancer. JAMA Neurol. 2016;73(8):928-33. 